\title{
PENGARUH PERLAKUAN LEACHING TERHADAP SIFAT MEKANIK FILM LATEKS KARET ALAM BERPENGISI SELULOSA MIKROKRISTAL DARI AMPAS TEBU
}

\author{
EFFECT OF LEACHING TREATMENT ON MECHANICAL PROPERTIES OF \\ NATURAL RUBBER LATEX FILM FILLED SUGARCANE BAGASSE \\ MICROCRYSTALLINE CELLULOSE
}

\author{
Rismadhani Elita*, Rojiyatul Ikhwani Lubis, Hamidah Harahap \\ Departemen Teknik Kimia, Fakultas Teknik, Universitas Sumatera Utara, \\ Jalan Almamater Kampus USU, Medan, 20155, Sumatera Utara, Indonesia \\ *Email : rismadhanielita@gmail.com
}

\begin{abstract}
Abstrak
Proses leaching merupakan salah satu faktor penting didalam menaikkan sifat mekanik produk lateks karet alam. Kajian tentang pengaruh leaching pada film lateks karet alam dengan pengisi selulosa mikrokristal dari ampas tebu dengan penyerasi alkanolamida dengan menggunakan suhu dan waktu vulkanisasi yang berbeda telah dilakukan untuk menghasilkan sifat mekanik seperti kekakuan tarik dan pemanjangan saat putus. Pembuatan film lateks karet alam dilakukan dengan teknik pencelupan berkoagulan. Penelitian ini dimulai dengan proses pra-vulkanisasi lateks karet alam pada suhu $70^{\circ} \mathrm{C}$ dengan pembebanan pengisi sebesar $0 \mathrm{phr}$, $5 \mathrm{phr}, 10 \mathrm{phr}$, dan $15 \mathrm{phr}$ dan diikuti dengan proses vulkanisasi pada suhu $100^{\circ} \mathrm{C}$ dan $150^{\circ} \mathrm{C}$ selama 10 menit dan 20 menit.Film yang didapat kemudian di lakukan perlakuan leaching menggunakan larutan air dan ammonia $1 \%$. Hasil uji kekuatan tarik film lateks karet alam menunjukkan nilai kekuatan tarik film lateks karet alam berpengisi selulosa mikrokristal dengan penyerasi alkanolamida setelah leaching lebih rendah dibandingkan nilai kekuatan tarik film lateks karet alam sebelum perlakuan leaching.
\end{abstract}

Kata kunci: leaching, alkanolamida,lateks karet alam, selulosa mikrokristal, suhuvulkanisasi, waktu vulkanisasi

\begin{abstract}
Leaching process is one of many factors to raise up the mechanical properties of latex products. Studies on the effect of leaching on film natural rubber latex with the filler microcrystalline cellulose from bagasse with alkanolamide using different temperatures and times vulcanization has been done to produce the better mechanical properties such as strenght tensile and elongation at break. Filming of natural rubber latex is done by coagulants dyeing techniques. The study started with the process of pre-vulcanised natural rubber latex at $70{ }^{\circ} \mathrm{C}$ with a loading filler by $0 \mathrm{phr}, 5 \mathrm{phr}, 10 \mathrm{phr}$ and $15 \mathrm{phr}$ and followed by a vulcanization process at a temperature of $100^{\circ} \mathrm{C}$ and $150^{\circ} \mathrm{C}$ for 10 minutes and 20 minutes. The film result will be have leaching treatment using a solution of water and ammonia $1 \%$. Test results of tensile strength of natural rubber latex film howed that the tensile strength of natural rubber latex film with microcrystalline cellulose as filler and alkanolamides after leaching less than the tensile strength of natural rubber lateks film before leaching.
\end{abstract}

Keywords: leaching, alkanolamides, natural rubber latex, microcrystalline cellulose, vulcanizationtemperature, vulcanization time

\section{Pendahuluan}

Lateks karet alam adalah getah pohon karet yang berwarna putih dan berbau segar. Lateks karet alam merupakan hasil penyadapan pohon Havea brasiliensisyang mengandung 30$40 \%$ partikel hidrokarbon karet, $2-2,5 \%$ protein [10].

Camila, et al (2010) telah meneliti tentang penggunaan tanah liat (clays) sebagai bahan pengisi dan Luo, et al (2013) meneliti tentang penggunaan silika sebagai bahan pengisi pada film lateks karet alam. Dimana hasil dari kedua penelitian tersebut menunjukkan adanya peningkatan sifat mekanik sepeti kekuatan tarik (tensile strength), kekuatan sobek (tear strength) dan densitas sambung silang (crosslink density) pada produk yang dihasilkan $[8,11]$.

Selain bahan pengisi di atas, jenis pengisi organik seperti selulosa, tepung kulit pisang, kitosan, dan tepung kulit singkong juga bisa digunakan untuk meningkatkan sifat mekanik lateks karet alam. Selain itu, hal yang perlu diperhatikan untuk meningkatkan sifat mekanik 
produk lateks karet alam adalah keserasian antara lateks karet alam dengan pengisi, terdapat kendala dimana sifat lateks karet alam yang nonpolar dan hidrofobik dan pengisiselulosa mikrokristal yangpolar dan hidrofilik menyebabkan keduanya kurang serasi. Oleh karena itu, diperlukan penambahan bahan penyerasi berupa surfaktan organik untuk memodifikasi pengisinya sehingga dapat berikatan lebih baik dengan lateks karet alam.

Surfaktan organik yang juga pernah digunakan dalam penelitian terdahulu adalah alkanolamida. Alkanolamida diperoleh dari hasil reaksi antara asam lemak turunan minyak sawit yaitu RBDPS (Refined Bleached Deodorized Palm Stearin) dengan dietanolamina [8].

Proses leaching sangat mempengaruhi sifat mekanik film, karena pada waktu pencucian dapat melarutkan bahan-bahan bukan karet seperti lemak, protein, karbohidrat, dan kotoran-kotoran lainnya [7]. Namun, pada proses leaching ini akan mengakibatkan modulus dan kekuatan tarik menurun. Lebih rendahnya modulus dan kekuatan tarik, mencirikan bahwa produk lebih nyaman dipakai [6]. Berbagai macam larutan leaching yang dapat digunakan yaitu, larutan kalium hidroksida $(\mathrm{KOH}) 1 \%$, Amonia 1\%, Air bersih, Natrium Hidroksida $(\mathrm{NaOH}) 1 \%$, dan alkohol : air $=1: 1$ [7]. Pada penetian ini akan digunakan larutan ammonia $1 \%$ dan air sebagai larutan leaching. Oleh karena itu diperlukan penambahan bahan penyerasi berupa surfaktan organik untuk memodifikasi pengisi sehingga interaksi antar lateks dan pengisi lebih baik. Dalam penelitian ini, bahan penyerasi yang digunakan adalah alkanolamida.

\section{Teori}

\section{Lateks Karet Alam}

Lateks karet alam yang berasal dari lateks Hevea Brasiliensis ini adalah cairan seperti susu yang diperoleh dari proses penorehan batang pohon karet. Cairan ini terdiri dari 30-40\% partikel hidrokarbon yang terkandung di dalam serum juga mengandung protein, dll [10].

\section{Pembuatan Senyawa Lateks Karet Alam}

Bahan-bahan kimia yang ditambahkan ke dalam lateks dapat digolongkan ke dalam 6 kategori pokok dengan berbagai fungsi dan kegunaannya masing-masing, yaitu sebagai berikut : [1]

Bahan Pemvulkanisasi (vulcanizing agent)

Bahan Pencepat Vulkanisasi (Accelerators)

- Bahan Penggiat Vulkanisasi (Activators Accelerators)

Bahan Penangkal (Antioksodant)

- Bahan Pemantap (Stabilizer)

- $\quad$ Bahan Pengisi (Filler)

\section{Selulosa Mikrokristal}

Selulosa mikrokristal adalah zat yang diperoleh dari selulosa kayu melalui proses hidrolisis asam dan merupakan bahan hasil pemurnian dan pemutihan produk dari kandungan lignin, hemiselulosa, dan bahan penghantar lainnya. Selulosa mikrokristal merupakan bahan berbentuk kristal putih, tidak larut dalam air atau asam, dan hampir semua pelarut orgnaik, tidak reaktif, free flowing, dan akan melunak pada kelembaban yang sangat tinggi tetapi akan reversibel ketika lingkungan berubah kelembabannya [4].

\section{Alkanolamida}

Alkanolamida adalah surfaktan non ionik dimana rantai hidrokarbon yang panjang bersifat non polar sedangkan gugus amidanya bersifat sangat polar. Oleh karena itu, diharapkan penggunaan alkanolamida dapat membuat interaksi antar fasa (interphase) antara mikrokristal selulosa dari ampas tebu dan latekskaret alam menjadi lebih kuat [3].

\section{Metodologi Penelitian \\ Bahan Penelitian}

Bahan yang digunakan dalam proses pembuatan produk lateks karet alam yang terdiri dari lateks karet alam, selulosa mikrokristal dari ampas tebu, alkanolamida, dan bahan kuratif lateks karet alam seperti sulfur, zink oksida $(\mathrm{ZnO})$, zinc diethyldithiocarbamate (ZDEC) dan antioksidan (AO). Bahan lain untuk dijadikan larutan leaching yaitu aquadest dan ammonia $1 \%$.

\section{Peralatan Penelitian}

Peralatan penelitian terdiri dari oven, hot plate, ceramic, rotary evaporator, vacum pump, neraca analitik, refluks kondensor, labu leher tiga, gelas ukur, beaker glass, vessel flask dan pelat seng. Peralatan uji meliputi uji sifat mekanik Universal Testing Machine (UTM) Gotech Al$7000 \mathrm{M}$, uji morofologi Scanning Electron Microscopy (SEM) JEOL-JSM-6510 LV, dan uji Fourier Transform Infra Red (FTIR) Shimadzu IR-Prestige 21.

\section{Metodologi Penelitian \\ Pembuatan Bahan Penyerasi Alkanolamida}

Alkanolamida disintesis dari bahan baku RBDPS dan dietanolamina. Sebanyak $50 \mathrm{~g}$ RBDPS dan 25,6g dietanolamina dimasukkan ke dalam labu leher tiga. Lalu ditambahkan $5 \mathrm{~g}$ katalis natrium metoksida (dilarutkan dalam methanol $20 \mathrm{ml}$ ).Campuran dipanaskan dan diaduk pada $60-70{ }^{\circ} \mathrm{C}$ selama 5 jam.Hasil reaksi diuapkan dengan alat rotary evaporator dan residu dilarutkan dalam $100 \mathrm{ml}$ dietil eter.Kemudian ditambahkan larutan $\mathrm{NaCl}$ jenuh hingga terbentuk dua lapisan.Diambil lapisan atas 
dan ditambahkan natrium sulfat anhidrat selama 45 menit lalu disarin dengan menggunakan kertas saring.Filtrat yang diperoleh diuapkan dengan alat rotary evaporator hingga pelarutnya habus. Residu yang dihasilkan dianalisis dengan analisa FTIR.

\section{Pembuatan Selulosa Mikrokristal dari Ampas Tebu}

Ampas tebu dicuci dan direndam selama 2 jam dan dikeringkan di sinar matahari selama 2 hari, lalu digunting dan diblender sampai halus. $50 \mathrm{~g}$ serat dipanaskan selama 2 jamdengan $700 \mathrm{ml}$ campuran $\mathrm{HNO}_{3} 3,5 \%$ dan $8 \mathrm{mg} \mathrm{NaNO}_{2}$. Lalu filtrat disaring dan dicuci hingga netral. Didigesti dengan $500 \mathrm{ml}$ larutan $\mathrm{NaOH} 2 \%$ dan $\mathrm{Na}_{2} \mathrm{SO}_{3} 2 \%$ pada $50^{\circ} \mathrm{C}$ selama 1 jam, lalu disaring dan dicuci hingga filtrate netral. Diputihkan dengan $340 \mathrm{ml}$ larutan $\mathrm{NaOCl} 3,5 \%$ dan air (1:1) hingga mendidih selama 10 menit, lalu filtrate disaring dan dicuci hingga netral. Dilakukan pemurnian $\alpha-$ selulosa dengan pemanasan pada $80^{\circ} \mathrm{C}$ selama 30 menit dengan $340 \mathrm{ml}$ larutan $\mathrm{NaOH} 17,5 \%$, selanjutnya filtrat disaring dan dinetralkan. Dilakukan pemutihan dengan $\mathrm{H}_{2} \mathrm{O}_{2} \quad 10 \%$ pada suhu $60^{\circ} \mathrm{C}$ dan dioven selama 1 jam, lalu diaring dan dicuci hingga filtrat netral dan dikeringkan menggunakan oven. Selanjutnya 5 g $\alpha$-selulosa dididihkan dengan $120 \mathrm{ml} \mathrm{HCl} 2,5 \mathrm{~N}$ selama 15 menit. Kemudian dituangkan ke dalam air dingin sambil diaduk mengunakan batang pengaduk dan dibiarkan hingga terbentuk suspensi. Suspensi yang dihasilkan dinetralkan dan dioven selama 1 jam pada suhu $30^{\circ} \mathrm{C}$.mikorkristal yang sudah kering disimpan dalam desikator.

\section{Pravulkanisasi dan Vulkanisasi Lateks Karet Alam}

Selulosa mikrokristal (MCC) dan alkanolamida terlebih dahulu didispersikan di dalam ball mill. Kadar MCC yang digunakan adalah $10 \%$ dan alkanolamida sebesar 0\% dan 2,5\%, sisanya adalah air. Larutan dispersi MCC dan alkanolamida tersebut diambil sebanyak $0 \mathrm{phr}$ (per hundred rubber), $5 \mathrm{phr}, 10 \mathrm{phr}, 15 \mathrm{phr}$ dan dicampurkan ke dalam lateks karet alam beserta bahan-bahan kuratif.

Proses pravulkanisasi dilakukan pada suhu $70^{\circ} \mathrm{C}$ hingga lateks karet alam telah matang dan angka kloroform telah menunjukkan angka 3 . Kemudian campuran didiamkan selama 24 jam. Lateks karet alam pravulkanisasi dicetak dengan menggunakan teknik pencelupan berkoagulan. Pelat seng terlebih dahulu dibersihkan dengan larutan asam asetat $10 \%$, aklium hidroksida $10 \%$, aquadest $10 \%$, dan kalium nitrat $10 \%$. Pelat seng yang telah bersih lalu dikeringkan dalam oven selama 5 menit pada suhu $100^{\circ} \mathrm{C}$.pelat seng didinginkan sebentar dan dicelupkan dalam lateks karet alam pravulkanisasi. Pelat seng dengan lateks karet alam pravulkanisasi dikeringkan dalam oven pada suhu $100^{\circ} \mathrm{C}$ dan $150^{\circ} \mathrm{C}$ selama 10 menit dan 20 menit. Produk lateks karet alam dipisahkan dari pelat seng dengan ditaburkan bubuk kalsium karbonat.

Produk lateks karet alam mengalami pengujian seperti uji densitas sambung silang (crosslink density) dengan standar internasional ASTM D471. Uji densitas sambung silang dihitung menggunakan persamaan Flory-Rehner seperti persamaan (1) berikut ini:

$$
\left(2 M_{C}^{-1}\right)=\frac{\left[-\ln \left(1-V_{r}\right)-V_{r}-\chi \cdot V_{r}^{2}\right]}{2 \cdot \rho_{N R L} \cdot V_{0}\left(V_{r}^{1 / 3}\right)}
$$

$\left(2 \mathrm{M}_{\mathrm{C}}{ }^{-1}\right)$ adalah densitas sambung silang, $\mathrm{V}_{0}$ dan $\chi$ adalah volume molar dan parameter interaksi dari pelarut (untuk toluen, $\mathrm{V}_{0}=108,5 \mathrm{~mol} . \mathrm{cm}^{-3}$ and $\chi=$ 0,39), $\rho_{\mathrm{NRL}}$ adalah densitas karet $=0,932 . \quad \mathrm{V}_{\mathrm{r}}$ adalah fraksi volume karet dalam gel yang membengkak dihitung dari persamaan (2) berikut ini:

$\mathrm{V}_{\mathrm{r}}=\frac{\mathrm{W}_{\mathrm{d}} / \rho_{\mathrm{d}}}{\mathrm{W}_{\mathrm{d}} / \rho_{\mathrm{d}}+\mathrm{W}_{\mathrm{sol}} / \rho_{\text {sol }}}$

$\mathrm{W}_{\mathrm{d}}$ adalah massa awal karet, $\rho_{\mathrm{d}}$ adalah densitas karet (untuk karet vulkanisasi, $\rho_{\mathrm{d}}=0,9203 \mathrm{~g} . \mathrm{cm}^{-3}$ ) $\mathrm{W}_{\text {sol }}$ adalah massa pelarut yang terserap dalam karet, dan $\rho$ sol adalah densitas pelarut (untuk toluene, $\rho_{\text {sol }}=0,87 \mathrm{~g} . \mathrm{cm}^{-3}$ ).

Uji sifat-sifat mekanik seperti uji kekuatan tarik (tensile strength) dan perpanjangan saat putus (elongation at break) dengan standar internasional ASTM D412.Morfologi patahan produk lateks karet alam dianalisis dengan SEM di Laboratorium SEM, Fakultas Matematika dan Ilmu Pengetahuan Alam, Universitas Negeri Malang.

Hasil

Densitas Sambung Silang (Crosslink Density)

Gambar 1 dan 2 menunjukkan hubungan waktu vulkanisasi, suhu vulkanisasi, pembebanan pengisi dan penambahan alkanolamida terhadap densitas sambung silang produk lateks karet alam.

Dari Gambar 1 dan 2terlihat bahwa densitas sambung silang meningkat seiring dengan peningkatan waktu dan suhu vulkanisasi serta pembebanan pengisi sampai $10 \mathrm{phr}$, sedangkan penambahan pengisi di atas $10 \mathrm{phr}$ akan menurunkan kembali nilai denisitas sambung silang karena penambahan pengisi menyebabkan ikatan antara pengisi (filler-filler bonding) dan menurunkan ikatan antar pengisi dan lateks (filler-rubber bonding). Interaksi antara lateks karet alam pengisi sangat diperlukan untuk menghasilkan produk yang baik [2].

Dari Gambar 1 dan 2 juga terlihat bahwa peningkatan suhu dan waktu vulkanisasi akanmeningkatkan nilai densitas sambung silang. 
Waktu vulkanisasi yang lebih lama dan suhu vulkanisasi yang lebih tinggi akan meningkatkan terjadiya reaksi sambung silang dan meningkatkan terjadinya pembentukan ikatan sambung silang. Hal ini dibuktikan dengan nilai densitas sambung silang yang lebih tinggi untuk waktu vulkanisasi 20 menit dibandingkan 10 menit, dan densitas sambung silang yang lebih tinggi pada suhu $150^{\circ} \mathrm{C}$ dari pada suhu $100^{\circ} \mathrm{C}$.

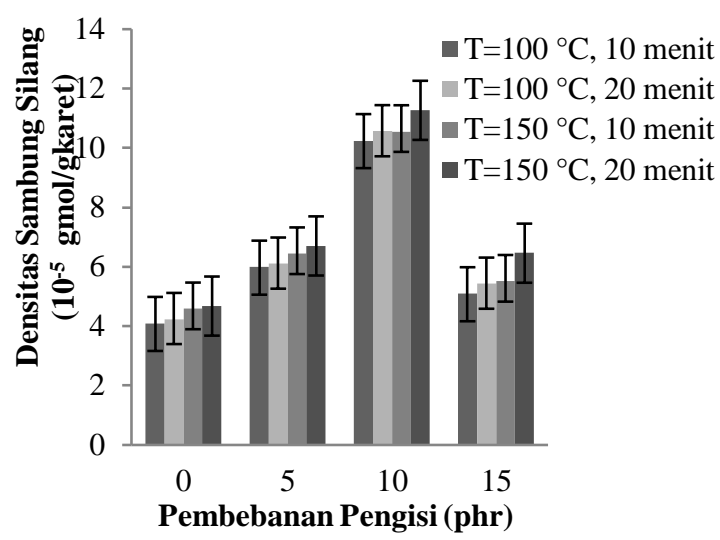

Gambar 1. Pengaruh Waktu Vulkanisasi, Suhu Vulkanisasi, dan Pembebanan Pengisi terhadap Densitas Sambung Silang Tanpa Penambahan Alkanolamida

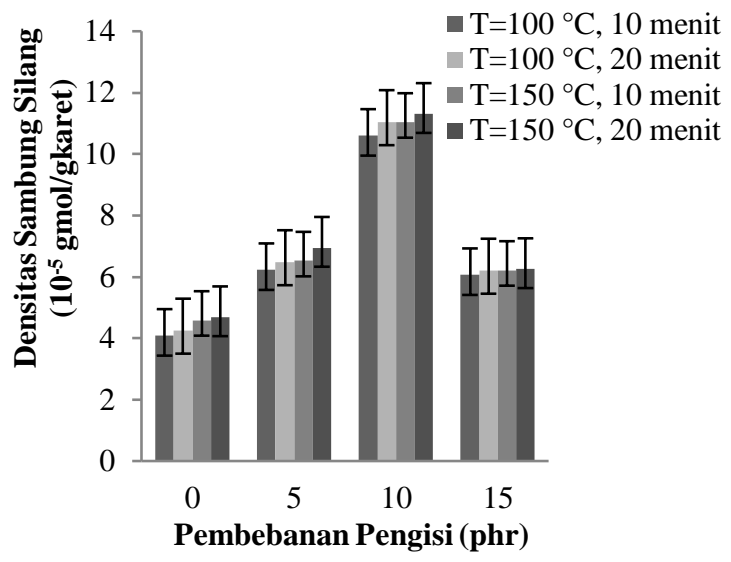

Gambar 2. Pengaruh Waktu Vulkanisasi, Suhu Vulkanisasi, dan Pembebanan Pengisi terhadap Densitas Sambung Silang dengan Penambahan Alkanolamida 2,5\%

Dari Gambar 1 dan Gambar 2 terlihat pengaruh penambahan alkanolamida terhadap densitas sambung silang film lateks karet alam. Dimana nilai densitas sambung silang film lateks karet alam menggunakan alkanolamida sebesar $2,5 \%$ lebih tinggi dibandingkan dengan nilai densitas sambung silang tanpa penambahan alkanolamida. Hal ini disebabkan penambahan alkanolamida meningkatkan keserasian antara lateks dan pengisi sehingga ikatan sambung silang yang dihasilkan semakin banyak.

Peningkatan suhu dan waktu vulkanisasi akan meningkatkan nilai densitas sambung silang.
Hal ini disebabkan karena peningkatan suhu dan waktu vulkanisasi akan meningkatkan keserasian antara lateks dan pengisi MCC yang digunakan, karena ikatan sambung silang lebih mudah terbentuk di suhu yang tinggi [5].

\section{Kekuatan Tarik (Tensile Strenght)}

Gambar 3 menunjukkan pengaruh perlakuan leaching terhadap kekuatan tarik (tensile strenght) produk lateks karet alam. Dari Gambar 3 dapat dilihat bahwa nilai kekuatan tarik (tensile strength) pada suhu $150{ }^{\circ} \mathrm{C}$ lebih tinggi dibandingkan dengan suhu vulkanisasi $100{ }^{\circ} \mathrm{C}$. Hal ini disebabkan oleh ikatan sambung silang yang terbentuk pada suhu vulkanisasi yang lebih tinggi adalah lebih banyak. Suhu vulkanisasi yang tinggi $\left(150{ }^{\circ} \mathrm{C}\right)$ menyebabkan filler dan lateks karet alam bereaksi lebih baik sehingga menghasilkan ikatan sambung silang yang lebih baik dibandingkan dengan suhu yang rendah (100 ${ }^{\circ} \mathrm{C}$ ) Suhu vulkanisasi turut berperan dalam menentukan sifat mekanik produk yang dihasilkan.

Peningkatan pembebanan pegisi selulosa mikrokristal dari ampas tebu sampai kadar $10 \mathrm{phr}$ dengan penyerasi alkanolamida akan meningkatkan kekuatan tarik dari film lateks karet alam. Hal ini disebabkan telah tercapainya nilai optimum dari film lateks karet alam. Penambahan pembebanan pengisi selulosa mikrokristal dengan penyerasi alkanolamida akan menyebabkan peningkatan nilai kekuatan tarik dari film lateks karet alam yang dihasilkan. Hal ini dapat disebabkan karena alkanolamida dapat bertindak sebagai bahan yang dapat meningkatkan kerapatan ikatan sambung silang dari film lateks karet alam yang dihasilkan.

Dari Gambar 3 juga dapat dilihat bahwa terjadi peningkatan nilai kekuatan tarik dari waktu vulkanisasi 10 menit sampai waktu vulkanisasi 20 menit untuk semua variasi suhu dan alkanolamida yang digunakan. Hal ini disebabkan dikarenakan semakin lama waktu vulkanisasi, maka jumlah densitas sambung silang bertambah yang akan menyebabkan meningkatkan nilai kekuatan tarik yang dihasilkan.

Dengan adanya perlakuan leaching mempengaruhi sifat mekanik dari film lateks karet alam. Dimana, perlakuan pencucian menggunakan larutan ammonia $1 \%$ mengalami penurunan kekuatan tarik daripada menggunakan larutan air. Sampel kontrol adalah sampel yang tidak diberikan perlakuan leaching. Hal ini dikarenakan larutan amonia $1 \%$ bersifat amfoter dalam keadaan basa, sehingga dapat meningkatkan kadar tereskstrak pada film lateks karet alam yang mengakibatkan film menjadi lebih lentur. Sedangkan pada air, kadar terekstrak pada film lebih rendah, hal ini dikarenakan air tidak bersifat amfoter dalam keadaan basa, 
sehingga air tidak signifikan merubah film lateks karet alam.

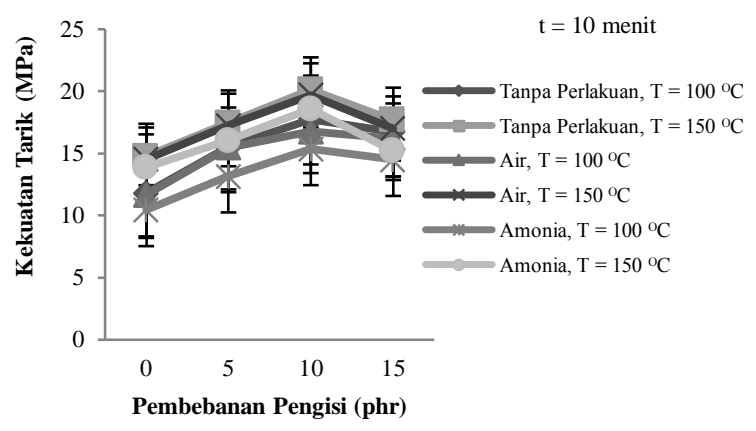

(a) Waktu Vulkanisasi 10 menit

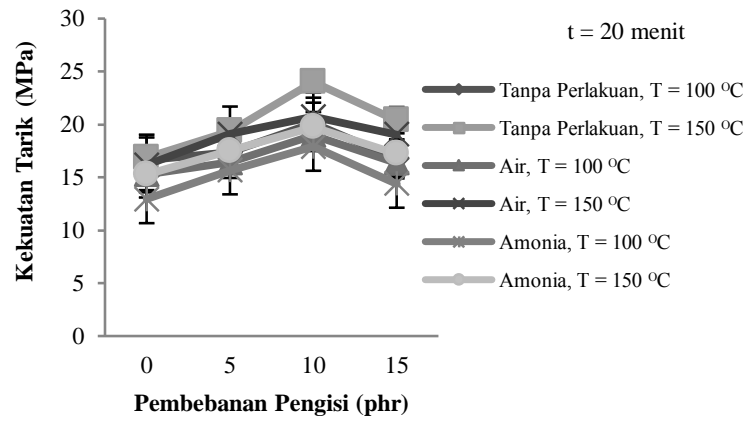

(b) Waktu Vulkanisasi 20 menit

Gambar 3. Pengaruh Perlakuan Leaching pada Suhu dan Waktu Vulkanisasi yang Berbeda terhadap Kekuatan Tarik Produk Lateks Karet Alam

\section{Pemanjangan Saat Putus (Elongation at Break)}

Gambar 4 menunjukkan hubungan perlakuan leaching terhadap pemanjangan saat putus produk lateks karet alam. Dari Gambar 4 dapat dilihat bahwa peningkatan suhu dan waktu vulkanisasi serta pembebanan pengisi akan menurunkan nilai elongation at break.

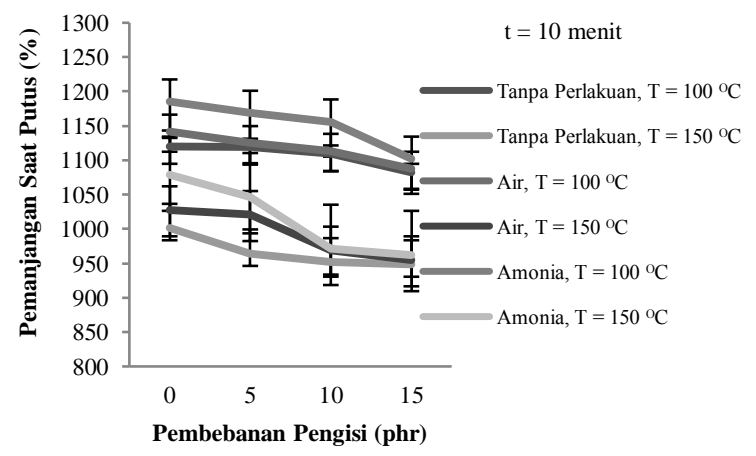

(a) Vulkanisasi 10 menit

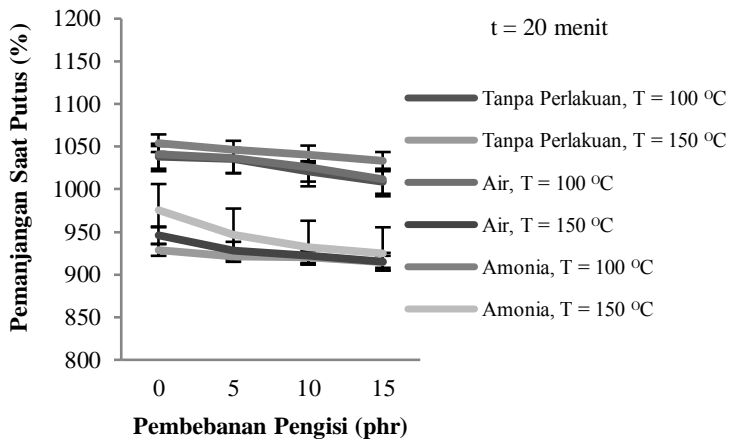

(b) Vulkanisasi 20 menit

Gambar 4. Pengaruh Perlakuan Leaching pada Suhu dan Waktu Vulkanisasi yang Berbeda terhadap Pemanjangan Saat Putus pada Film Lateks Karet Alam

Seperti telah dijelaskan sebelumnya, waktu dan suhu vulkanisasi yang lebih besar akan meningktakan nilai densitas sambung silang. Semakin besar nilai densitas sambung silang maka produk yang dihasilkan cenderung lebih rapuh sehingga sifat elastisnya akan menurun. Penambahan MCC sebagai pengisi akan membuat nilai pemanjangan saat putus semakin menurun. Hal ini disebabkan MCC mengandung selulosa yang memberikan efek kekakuan (stiffening effect) pada produk lateks karet alam. Selulosa memiliki ikatan hidrogen yang kuat dan tidak mudah larut dalam pelarut yang umum [2].

Sampel kontrol merupakan sampel lateks karet alam tanpa perlakuan leaching. Pada Gambar 4 dapat dilihat untuk perlakuan leaching menggunakan larutan ammonia $1 \%$ pemanjangan putusnya meningkat dibandingkan menggunakan air. Semakin baik larutan leaching melakukan estrak maka akan semakin tinggi pemanjangan putusnya. Hal ini disebabkan diameter partikel rata-rata pada film lateks menjadi lebih kecil dan merata. Hal ini dapat dilihat pada Gambar 5. Dengan demikian, film lateks yang dihasilkan menjadi lebih lentur [9].

\section{Karekteristik Scanning Electron Microscope (SEM) pada Produk Film Lateks Karet Alam}

Gambar 5 merupakan hasil dari analisa Scanning Electron Microscope untuk film sebelum perlakuan leaching dan sesudah perlakuan leaching menggunakan ammonia $1 \%$.

Dari Gambar 5 terlihat perbedaan permukaan film sebelum leaching dan sesudah leaching. Dimana permukaan film lateks setelah di leaching mengalami perubahan diameter yaitu memiliki ukuran 0,05 - $1 \mu$. Sedangkan yang tidak di leaching memiliki ukuran $0,05-3 \mu$. Pada larutan ammonia $1 \%\left(\mathrm{NH}_{3}\right)$ kadar yang terestrak lebih banyak dibandingkan air, hal ini disebabkan karena partikel yang menyebabkan alergi seperti protein, karbohidrat, dan lemak 
terestrak pada larutan yang bersifat amfotir bersifat basa (larutan amonia), daya kelarutannya lebih tinggi daripada dalam keadaan netral sehingga akan menyebabkan permukaan film menjadi rata, tipis, dan diameter partikel menjadi lebih kecil [7].

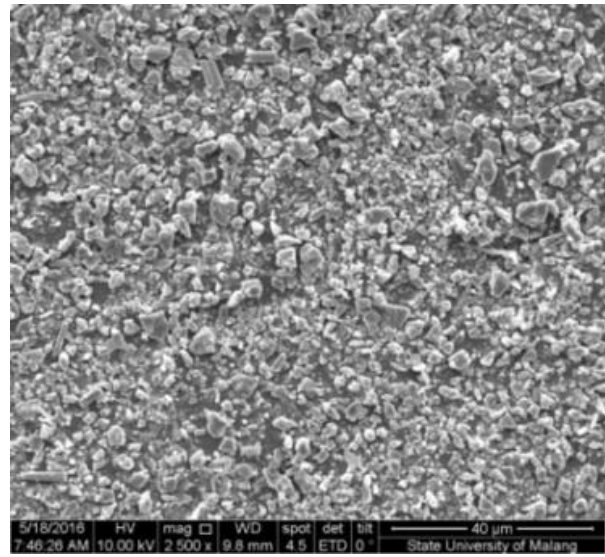

(a) Sebelum Leaching

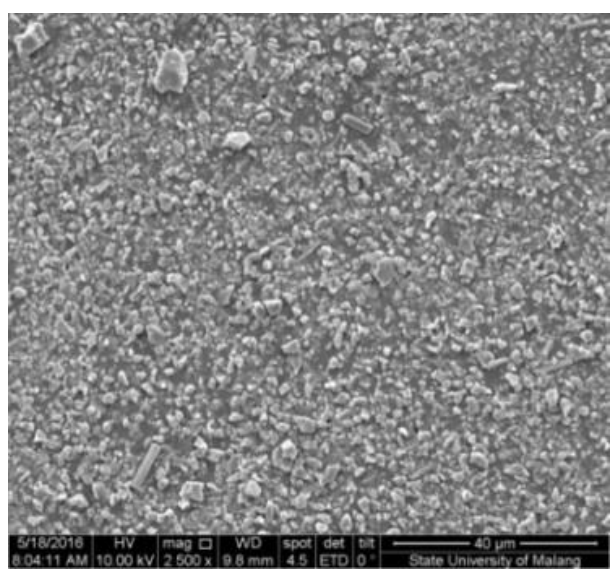

(b) Sesudah Leaching

Gambar 5. Karekteristik Scanning Electron Microscope Patahan Film Lateks Karet Alam

\section{Kesimpulan}

Alkanolamida sebagai bahan penyerasi memiliki gugus polar yang mampu memodifikasi MCC dan gugus non polar yang mampu memodifikasi matriks lateks karet alam. Penambahan alkanolamida dapat meningkatkan kekuatan mekanik pada film lateks karet alam. Waktu vulkanisasi dan suhu vulkanisasi yang meningkat dapat meningkatkan nilai densitas sambung silang. Penambahan pengisi MCC hingga $10 \mathrm{phr}$ akan meningkatkan nilai densitas sambung silang. Perlakuan terbaik untuk kekuatan tarik terdapat pada produk lateks karet alam dengan waktu vukanisasi 20 menit, suhu vulkanisasi $150{ }^{\circ} \mathrm{C}$, pembebanan pengisi $10 \mathrm{phr}$ dan penambahan alkanolamida dengan kadar $2,5 \%$.
Hasil analisa Scanning Electron Microscopy, proses leaching dapat merubah permukaan film lateks karet alam berpengisi selulosa mikrokristal dengan penyerasi alkanolamida, dimana permukaan memiliki diameter partikel rata-rata lebih kecil dibandingkan sebelum perlakuan leaching yang mengakibatkan perubahan sifat mekanik film lateks, yaitu kekuatan tarik. Perlakuan leaching mengakibatkan pemanjangan saat putus pada film lateks karet alam meningkat, hal ini juga diakibatkan adanya penambahan alkanolamida dimana sifat dari alkanolamida sebagai pemlastik yang akan meningkatkan deformasi.

\section{Daftar Pustaka}

[1] A. R. Fachry, I. S. Tuti, A. P. Bobi, dan A. K. Dwi. Pengaruh Penambahan Filler Kaolin terhadap Elastisitas dan Kekerasan Produk Souvenir dari Karet Alam (Havea bransiliensis). Prosiding SNTK TOPI. Pekanbaru, 2012.

[2] H. Harahap, K. Hardinatan, A. Hartanto, E. Surya, dan I. Surya. Pemanfaatan Limbah Kulit Singkong Termodifikasi Alkanolamida Sebagai Bahan Pengisi dalam Produk Lateks Karet Alam : Pengaruh Waktu Vulkanisasi. Majalah Kulit, Karet, dan Plastik Vol. 31 No. 1 Juni Tahun 2015 : 01-08, 2015.

[3] J. R. Oppusunggu, V. R. Siregar, Z. Masyithah. Pengaruh Jenis Pelarut dan Temperatur Pelarut Reaksi pada SIntesis Surfaktan dari Asam Oleat dan n-Metil Glukamina dengan Katalis Kimia. Jurnal Teknik Kimia USU, Volume 4, No 1, 2015.

[4] K. Pratiwi. Formulasi Tablet Ekstrak Buah Pare (Momordica charantia L.) dengan Variasi Konsentrasi Bhana Pengikat Gelatin Secara Garnulasi Basah. Skripsi Diploma 3 Farmasi, Fakultas Matematika dan Ilmu Pengetahuan Alam. Universitas Sebelas Maret : Surakarta, 2011.

[5] M. Isra, Irdoni, dan Bahruddin. Pengaruh Suhu dan Tekanan Vulkanisasi terhadap Morfologi dan Sifat Karet Alam Vulkanisasi (Thermoset Rubber) dengan Filler Abu Sawit/Carbon Black. Laboratorium Teknologi Bahan Alam dan Mineral. Jurusan Teknik Kimia Fakulta Teknik Universitas Riau : Pekanbaru, 2010.

[6] M. Sumarti, M. Utama, dan D. Listina, Pengaruh Pencucian dan Pemanasan terhadap Sifat Fisik Mekanik Barang Celup dari Lateks Alam Iradrasi. Pertemuan ILmrah Penelitian dan Pengembangan Aplikasi Isotop dan Radiasi, 2001.

[4] M. Utama, Herwinarni, M. Sumarti, Siswanto, Suharyanto, Yoharm. S, 
Bambang Habdoko, H. Sundaru, T. Haryono, dan H.M. Muklis, Uji Produksi Karet Tensimeter Bebas Nitrosamin dan Protein Alergen dalam Skala Pabrik. Indonesian Journal of Materials Science, ISSN.1411-1098, Vol. 6, No. 1, 2004.

[8] R. A. Camila, C. B. Fabio, R. D. Telma, T. L. Lay, G. Fernando, dan B. Franscois. Natural Rubber-Clay Nanocomposites: Mechanical and Structural Properties. University of Campinas, Brazil, 2010.

[9] S. Prihatin, Marga Utama, dan Wiwien Andriyanti, A Review on The Rubber Products From Irradiation Vulcanization Natural Latex. Prosiding Seminar Nasional Kulit, Karet, dan Plastik, 2014.

[10] W. Andriyanti, Darsono, dan F. Wisjachuddin. Kajian Metode Vulkanisasi Lateks Karet Alam Bebas Nitrosamin dan Protein Alergen. Prosiding PPI-PDIPTN 2010, Pustek Akselerator dan Proses Bahan BATAN : Yogyakarta, 2010.

[11] Y. Luo, F. Chunfung, W. Qinghuang, Y. Zhefeng, Q. Quanfang, K. LX, dan P. Zheng. Preparation and Characterization of Natural Rubber/Silica Nanocomposites using Rule of Similarity in Latex.Journal of Wuhan University of Technology Matter, Vol. 28, No. 5, 2013. 